\title{
Introduction: the immigration detention puzzle in interdisciplinary perspective
}

\author{
Michael J. Flynn and Matthew B. Flynn
}

\section{STARTING WITH HUTTO}

The seeds for this book were initially sown in April 2010, when the volume's two editors visited the misleadingly named T. Don Hutto Residential Center, a women-only immigration detention center located near Austin, Texas. The visit was part of a larger research initiative of the Geneva-based Global Detention Project (GDP) to assess the use of privately operated immigration detention centers in the United States and elsewhere. ${ }^{1}$ The editors interviewed recently detained women from Central America to get their views on the conditions of their confinement ${ }^{2}$ and one of us was given a guided tour of Hutto at the invitation of US Immigration and Customs Enforcement (ICE). ${ }^{3}$

For several years preceding this visit, the facility-which previously had been called the Hutto Family Residential Facility-was one of only two US centers used to detain families in what critics described as punitive and severely unsuitable conditions. Named after a pioneer in prison privatization and co-founder of the company that owns Hutto (the Corrections Corporation of America ${ }^{4}$ ), the Hutto facility is located in a former prison that was converted to a family detention center in 2006 at the behest of Congress.

Much of Hutto's backstory is discussed in two of the chapters of this volume: one by an award-winning New York Times journalist (Nina Bernstein) whose pioneering work on immigration detention during the first decade of the 2000s helped turn it into a national issue in the United States; the other by a former federal immigration official and prison administrator (Dora Schriro) who was tasked by the first Barack Obama administration with initiating reforms in the country's sprawling immigration detention system to shift it from an inappropriately penal to a "truly civil" detention model. Although both authors address the same subject matter-the US government's failure to implement meaningful detention reforms, particularly with respect to the detention of children and 
families - their chapters are very different. Bernstein discusses the reasons why growing media attention on immigration detention was inadequate to spur lasting changes; Schriro provides an insider's view on the reasons the reform process fell short. Despite their differing perspectives, the two writers agree on the urgency of the situation today, especially with a new, more hardline anti-immigrant administration in the White House.

The lessons that emerge from Bernstein's and Schriro's analyses of efforts to challenge the detention of children in the United States help illustrate the need for and value of interdisciplinary research into immigration detention. As Schriro relates, in the years before Hutto opened, when non-citizen families were detained for immigration reasons, mothers and fathers were separated from their children. This practice was opposed by some members of Congress on humanitarian grounds, eventually leading - with no small amount of irony - to the opening of the Hutto "family residential" detention facility, a widely criticized facility whose appalling conditions of detention for children were the subject of numerous lawsuits and demonstrations. Schriro documents the failures in policy-making since that time that ultimately laid the groundwork for the mass detention of Central American children along the US-Mexico border in recent years. Among the significant impediments to reform she highlights was the Obama administration's decision to establish a reform initiative in the Department of Homeland Security - at the Office of Detention Policy and Planning - which was empowered to propose solutions and dialogue with stakeholders outside government, but prevented from actually implementing changes.

For her part, Bernstein notes how, during her brief tenure, Schriro was able to produce the "most comprehensive analysis of immigration detention to date," a "devastatingly critical" report on "a system that had grown willy-nilly, without even basic tools for measuring performance" (p. 22). However, in highlighting one of the many instances when effective news reporting on immigration detention was undercut, Bernstein notes how even before the Schriro report was released and its proposed reforms were reported, the Obama administration had "gotten ahead" of the news about it "by announcing the overhaul in advance. Now the focus of news coverage was not on Schriro's findings, but on steps taken since the August announcement." Bernstein adds that the reform effort "included advisory groups soliciting the advice of activists and detainee advocates - in effect, quieting them, if not co-opting them, for many months to come" (p. 22). As became clear to us - the two editors of this volume - much later, we were arguably amongst those being "co-opted" by being given a tour of the government's new showcase facility, the Hutto women's facility.

By the time we arrived at Hutto in April 2010, the facility had undergone an intense makeover, becoming a centerpiece in the Obama 
administration's efforts to put a kinder, gentler face on detention. Such was its apparent transformation from notorious imprisoner of children to supposedly friendly lockup of immigrant women that one detainee we spoke with - a woman from Honduras who had previously been detained at other Texas detention centers - asked if we knew of any way to ensure that she would be detained again at Hutto in the event that she was apprehended during her next attempt to come to the United States (where her US-born children lived).

To reach Hutto, you have to drive through a low-income neighborhood located on the outskirts of the small town of Taylor, Texas. After passing several blocks of run-down homes and abandoned barns, you come upon a large open field, at the end of which is a set of buildings surrounded by fences and barbed wire. Inside, the detention center is comprised of several pods - or living areas - each with two levels of individual cells and an open area in the center. There is also a central cafeteria, a large gym, a library, a computer room, medical facilities and outdoor recreation areas. Through the wide and high-ceilinged hallways one can observe inmates walking about freely from one section of the facility to the next, which they are allowed to do from early morning to early evening, when they must return to their cells.

During his guided tour of the facility, one of the editors of this volume was introduced to numerous staff representing both the Corrections Corporation of America and ICE, and given a personalized tour by the facility warden and a representative of ICE based at the facility. ${ }^{5}$ The tour included a visit to one of the pods. When we entered the pod, all the female detainees - apparently on cue and under orders - stood and began to clap, bringing a beaming smile to the face of the male warden.

After the tour, we sat with facility staff and on-site medical personnel to discuss our impressions. One staff member claimed that the working environment at Hutto was extremely warm and positive, and that this attitude had a positive impact on the demeanor of the detainees. The warden explained that the facility exhibited an open and relaxed security environment because the women detained there were hand-picked based on their non-threatening profiles and track records. When asked why, if the women were not a threat, they were detained without charge at such high costs in the first place, one of the staff responded - not without reasonthat that was a question for the policy-makers.

\section{THE IMMIGRATION DETENTION PUZZLE}

The peculiarities of Hutto are not unique to that facility. In fact, across the globe today immigration detention centers are in operation under 
countless forms and guises, sometimes hidden behind misleading names like Hutto's, often having much more severe and inhuman conditions, and nearly always buttressed by contradictory and self-defeating political, social and economic policies. How to explain the apparently inexorable growth of a policy that costs countless millions of dollars, damages the health and well-being of perhaps hundreds of thousands of people every year, and yet ultimately has so little impact on the realities of global immigration and refugee flows? This is the puzzle that is at the heart of this book, and understanding this puzzle is - this book contends - necessary to successfully challenging it.

It is supposed to be in the nature of puzzles that they can be put back together again. But with a puzzle like immigration detention in which the pieces come in so many different shapes and sizes, it is difficult just to find the corner and side pieces, let alone all the pieces in the middle. What is more, many of the critical pieces - like coherent laws, comparable statistics or basic transparency - do not even exist. This book does not attempt to create a unifying theory or school of thought that can serve as a manual to put all the detention pieces back together again. Nor does it push a specific reform agenda or a single set of policy proposals. Rather, it provides a forum for the interdisciplinary exploration of strategies and analyses that are aimed at contesting the logic and growth of immigration detention.

The various rationales for the book, which gradually emerged in the editors' numerous conversations and papers since our visit to Hutto in 2010, are tied together by several interlocking realizations: First, that the detention of immigrants and asylum seekers for reasons related to their immigration status ${ }^{6}$ has reached global proportions and appears to be expanding still, involving unknown thousands of people every year, many of whom are locked up in inhuman conditions and often in a legal vacuum that prevents them from accessing even basic guarantees and protections. On the other hand, given the massive and complex scope of this predicament, we realized that to challenge damaging detention policies and practices would require a sophisticated, multi-faceted approach, one that is capable of critically assessing the many dimensions of this phenomenon.

The very nature of immigration-related detention necessitates such an approach. Detention occurs at borders, across borders and sometimes between borders; it plays a central role in global "migration management" initiatives that can involve international organizations, multinational security corporations, non-governmental organizations, and uneasy alliances of poorer and wealthier countries vying for advantage; it is driven by often complex political and economic realities encompassing domestic and interstate politics, business interests, and competing visions 
of global peace and security; and the laws and official rhetoric buttressing detention practices employ a bewildering array of linguistic strategies and justifications aimed at excluding unwanted non-citizens from public space.

We are far from the first writers to recognize the complex "messiness" of immigration detention and the need for interdisciplinary approaches. As the authors of the chapter on geography in this volume write, geographic research in immigration detention "calls into question and, often, defies disciplinary boundaries. This interdisciplinarity is significant, we suggest, because it emphasizes an orientation that explicitly recognizes the 'messiness' of borders, whether they are conceptual, sovereign, political or physical" (Conlon, Hiemstra and Mountz, p. 141).

Also, as this volume attests, the problematic nature of immigration detention has drawn the attention of an ever-broadening scope of scholars, activists, writers and policy-makers from an array of disciplines and professional backgrounds, who over the last two decades have published countless pages on the subject. And yet, as Bosworth (p. 54) underscores in her chapter discussing insights from criminology, despite this "growing, interdisciplinary set of publications on border control practices around the world," numerous questions remain as well as gaps in our understanding of seemingly obvious topics like "the social and cultural world of immigration detention centers."

Thus was born the idea of this volume: even though different practitioners and academic schools engaging detention have recognized the need to incorporate tools and insights from other disciplines to answer questions they are raising, to date few efforts have been made to invite practitioners from widely divergent disciplines and professions into a single, coherent conversation. How does the work of investigative journalists illuminate the efforts of policy-makers to explain their failure to end the detention of families and children? Do activists fighting their own detention and deportation struggles agree with the strategies of global movements promoting alternatives to detention? Do experts from United Nations (UN) agencies, international advocacy organizations and academic programs find similar value in using human rights norms to challenge the excesses of immigration detention regimes? What can the efforts of mental health practitioners working with detainees tell us about the philosophy behind prison inspectors seeking to improve the conditions of detention in removal centers?

With these types of questions in mind, the editors of this volume invited a diverse group of widely recognized experts in their fields to discuss how their disciplines have challenged immigration detention, including everything from the underlying socio-political logic undergirding this practice to the lived realities of detention. To encourage the cross-disciplinary nature 
of the volume, we asked each of the authors to carefully explain their terminology and argumentation in order to open up their questions and answers to scrutiny beyond their specific schools of thought and strategic positions. Lastly, we asked the authors to review and comment on early drafts of other chapters in the volume from different disciplines. The result is this book, Challenging Immigration Detention: Academics, Activists and Policy-makers.

\section{CHAPTER OVERVIEW}

The failure by the Obama administration to implement lasting immigration reforms, particularly with respect to the detention of children and families, has been a major blow to hundreds of thousands of undocumented migrants, asylum seekers and their supporters. Given the threatening and regressive policies of the Trump administration, this failure may prove to be one of Obama's most far-reaching and painful legacies. Thus, we open the book with two chapters that deepen the debate over efforts to reform family detention in the United States, offering outsider and insider perspectives. Nina Bernstein, a reporter for the New York Times, has written extensively about the growth of immigration detention in the United States. In her focus on the Obama administration's efforts to create a "truly civil detention system," she outlines the challenges faced by investigative journalists reporting about immigration detention as well as the limited albeit necessary role of an independent media for creating change. Dora Schriro, former Special Advisor to the US Department of Homeland Security under Obama, provides an insider's view of the failed efforts to roll back the detention of women and children, as well as the surge in detention of children arriving from Central America in the summer of 2014 that spelled the end of any nascent reforms.

The struggles and setbacks experienced in the United States have many parallels to reform efforts in the United Kingdom, where promises made by politicians about ending the detention of families have failed to translate into lasting change. The next two chapters, written by two wellregarded immigration detention experts in the United Kingdom, highlight the inescapable relationship between criminal and immigration law when it comes to immigration-related detention, one from the perspective of a criminologist and the other constitutional law. In Chapter 3, Oxford's Mary Bosworth focuses largely on immigration detention policies in the United Kingdom in tracing the development of harsher immigration penalties like detention measures as a by-product of the convergence of criminal and immigration law, which has led to increases in the numbers of deten- 
tion facilities and detainees. She argues that the emerging field of border criminology offers unique insights, tools and critiques for understanding the policing, imprisonment and detention of migrants. In Chapter 4, legal expert and UK immigration judge Daniel Wilsher analyses the legal challenge to separating immigration detention from criminal punishment in the context of constitutional law and the principles of liberal democracies, reviewing the laws in several key detaining countries. He highlights how the broad acceptance by courts that migration authority entails a power to detain pending expulsion has made it difficult to draw clear boundaries around detention. This has allowed governments to extensively expand detention efforts. However, his analysis reveals that countries with civil law traditions appear to offer more protections than legal systems based on common law.

Chapters 5, 6 and 7 provide diverging visions of how advocates can challenge detention systems, working at three distinct levels: as a representative of an official national human rights institution (Hindpal Singh Bhui); as an undocumented activist (Claudia Muñoz and Michael Young); and as a global campaigner (Grant Mitchell). Bhui, who works for Her Majesty's Inspectorate of Prisons in the United Kingdom (HMIP), the institution responsible for inspecting prisons and detention centers, addresses the dilemma facing human rights activists working outside of the system compared to those on the inside. Using the history and development of the HMIP as a case in point, he argues that advocates promoting change from outside may be less uncompromising in their positions, but arguably they are less able to promote meaningful change for people in detention. In contrast, detainee advocates working from inside the system do not call into question the detention system yet nonetheless can promote tangible improvements in the lives of detainees. Muñoz and Young directly challenge this notion, arguing that direct action and civil disobedience have been overlooked strategies. They detail the activism of the National Immigrant Youth Alliance (NIYA), who have "infiltrated" several detention facilities in the United States, exposing the brutal treatment of detainees and gaining the release of many asylum seekers. The authors argue that the NIYA case calls into question prevailing theories of effective social movements. Finally, Grant Mitchell from the International Detention Coalition provides yet another view of the efficacy of advocacy, reflecting on the challenges of creating a global campaign promoting "alternatives to detention" and assessing non-detention models that appear to have had some success in various countries.

The effectiveness of strategies pushing non-detention models depends on a range of political and economic circumstances. The following three chapters provide perspectives from social scientists on how the social 
context of detention shapes advocacy efforts. In Chapter 8, co-authors Conlon, Hiemstra and Mountz offer critical perspectives from the discipline of geography for mapping out the use of "space as a means of social control." They draw attention to places where detention practices can be disrupted and how sites offer opportunities for social mobilization. Using the lens of critical theory, in Chapter 9 De Genova advances the concept of detainability in order to understand the legal non-personhood of immigrants and the sovereign power to detain people indefinitely. In so doing, he analyses the different circumstances that undergird various degrees by which distinct categories of migrants are subjected by this susceptibility to the detention power. In Chapter 10, Flynn considers the role of economic factors and labor markets in the rise and spread of detention systems. He argues that the spread of global market forces has increased economic insecurities that further out-migration from sending countries while at the same time exacerbating xenophobic attitudes in receiving countries. Still, national variation in state institutions and the character of state-business networks shape the degree to which governments employ detention practices to discipline labor and their use of private firms to administer facilities.

Chapter 11 provides accounts by leading mental health professionals in Australia (Brooker, Albert, Young and Steel) who work with detainees suffering from the pernicious psychological impact of immigration detention. Immigration facilities form an "invalidating environment" that promotes emotional and behavioral dysregulation, especially on asylum seekers who have been held for long periods of time. Despite the harsh conditions, psychologists have used various clinical techniques to help asylum seekers develop resilience and coping mechanisms for addressing their predicaments.

There are important regional differences and use of varied bilateral and multilateral mechanisms for upholding the normative right of liberty. The next two chapters contrast the experiences of the European Union and South America. The European Union (EU), explains international legal expert Galina Cornelisse in Chapter 12, has increasingly ramped up legal norms protecting the personal liberties of immigrants. EU directives, as well as decisions by the European Court of Human Rights and the European Court of Justice, have resulted in "novel litigation strategies" that resulted in important legal changes favorable to refugees and immigrants and offer examples for civil society to pursue at the transnational level. While regional governance is not as instituted in South America as in the EU, Pablo Ceriani Cernadas, a member of the UN Committee on the Rights of Migrant Workers, reviews in Chapter 13 the commitment by South American countries not to criminalize or arbitrarily 
detain irregular migrants and instead recognize migration as a right to be protected and fulfilled. As such, the region follows the evolution of human rights standards, while the use of detention by much of the rest of the world is an ineffective and harmful aberration.

Moving from the regional to the global level, in Chapter 14 Mariette Grange and Izabella Majcher from the GDP discuss how the emergence of immigration detention as a global phenomenon has taken place against the backdrop of the consolidation of the international human rights and humanitarian legal regimes. They provide a comparative assessment of the impact and implementation of fundamental human rights norms, dating back to the 1948 Universal Declaration of Human Rights, on contemporary immigration detention policies as well as how strategic approaches to UN bodies can be used to challenge unlawful practices.

In the concluding chapter, "The Many Sides to Challenging Immigration Detention," Michael Flynn, Executive Director of the GDP, offers some final thoughts about the insights provided in the various chapters and outlines future avenues for research and advocacy. He stresses the tension that can exist between efforts to promote the right to liberty and efforts to protect the right to security of person of those in detention, asking whether advocacy that focuses on only one part of this duality can have the unintended impact of buttressing the logic and practice of immigration detention. He concludes by emphasizing the development of strategies and tactics that are interdisciplinary, that take into account the complex political and historical reality of detention regimes while at the same time responding to the needs of immigrants, asylum seekers and the communities in which they live.

\section{NOTES}

1. The Global Detention Project is a non-profit research center based in Geneva, Switzerland that investigates the use of immigration-related detention as a response to global migration. Its objectives are: to improve transparency in the treatment of detainees; to encourage adherence to fundamental norms; to reinforce advocacy aimed at reforming detention practices; and to promote scholarship and comparative analysis of immigration control regimes. For more information, see https://www.globaldetentionpro ject.org/.

2. Bob Libal of the Austin-based Grassroots Leadership, which helped lead activist efforts to close Hutto, was instrumental in assisting the two editors in setting up interviews with detainees.

3. Michael Flynn was given a tour of Hutto on 19 April 2010 at the invitation of the head of the Juvenile and Family Residential Management Unit of the US Immigration and Customs Enforcement Detention and Removal Office.

4. In October 2016, CCA changed its name to CoreCivic. 
5. Michael Flynn's tour was overseen by ICE Supervisory Detention and Deportation Officer George Robertson.

6. This is the GDP's definition for "immigration-related detention": "The deprivation of liberty of non-citizens for reasons related to their immigration status." As readers will see throughout this book, the precise definition for this issue can change from scholar to scholar. It remains to some extent a contested concept. But the GDP's definition is suitable for circumscribing the particular phenomenon addressed in this book. 